
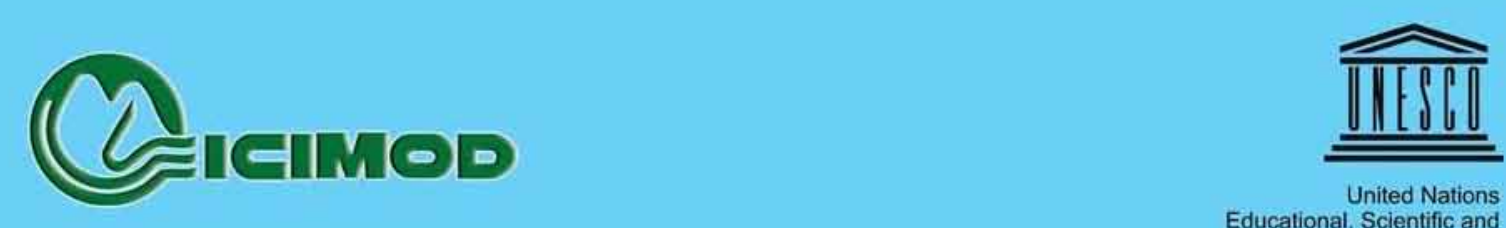

\title{
Preparing for Flood Disaster
}

Mapping and Assessing Hazard in the Ratu Watershed, Nepal
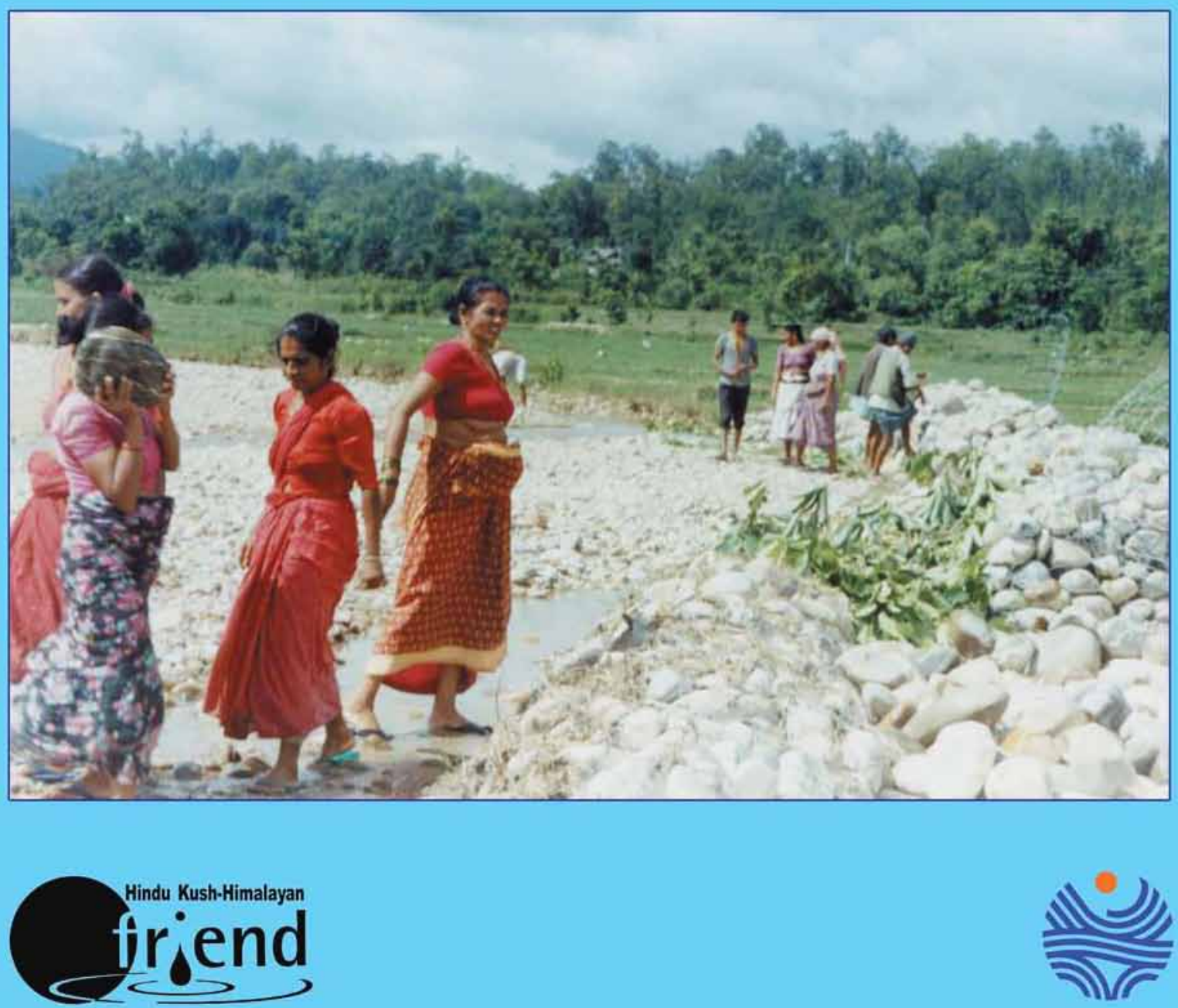

Narendra R. Khanal

Mandira Shrestha

Motilal Ghimire 


\section{About the Organisations}

The International Centre for Integrated Mountain Development (ICIMOD) is an independent 'Mountain Learning and Knowledge Centre' serving the eight countries of the Hindu Kush-

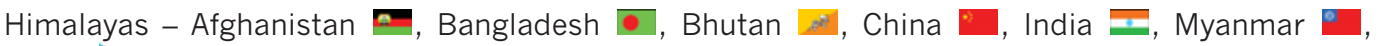

Nepal $\mathbf{E}$, and Pakistan $\mathbb{C}_{-}$- and the global mountain community. Founded in 1983, ICIMOD is based in Kathmandu, Nepal, and brings together a partnership of regional member countries, partner institutions, and donors with a commitment for development action to secure a better future for the people and environment of the extended Himalayan region. ICIMOD's activities are supported by its core programme donors: the governments of Austria, Denmark, Germany, Netherlands, Norway, Switzerland, and its regional member countries, along with over thirty project co-financing donors. The primary objective of the Centre is to promote the development of an economically and environmentally sound mountain ecosystem and to improve the living standards of mountain populations.

The International Hydrological Programme (IHP) is UNESCO's cooperative programme in water research, water resources management, education, and capacity-building, and the only broadlybased science programme of the UN system in this area. In existence for over 30 years now, IHP is committed to developing the science of hydrology at the service of society. Its primary aim is to draw together scientists worldwide in order to establish the scientific and technological bases for the rational management of water resources with respect to water quantity and quality.

The Hindu Kush-Himalayan Flow Regimes from International Experimental and Network Data project (HKH-FRIEND), is a regional network for hydrological research and data exchange. It is one of the eight research groups in the International FRIEND Project under UNESCO's International Hydrological Programme (IHP). The project evolved through a series of regional consultations initiated jointly by UNESCO, ICIMOD, and regional countries since 1989 and was formally established in 1996. ICIMOD has provided the Secretariat for HKH-FRIEND since its inception and also houses its Regional Hydrological Data Centre (RHDC). HKH-FRIEND works through collaboration and partnerships - national, regional, and international - and has received financial support from UNESCO/IHP; the German IHP/OHP National Committee; World Meteorological Organization (WMO); Federal Institute of Hydrology, Germany; Department for International Development (DFID) and Centre for Ecology and Hydrology (CEH), UK; and ICIMOD.

The data and information exchange will facilitate research on the hydrology and water resources of the Hindu Kush-Himalayan region and contribute towards improved management of water resources, such as flood forecasting, climate change impacts on water resources, hydropower development, and assessment of fresh water resources, and contribute towards sustainable development of water resources for poverty alleviation in the region. 


\section{Preparing for Flood Disaster}

Mapping and Assessing Hazard in the Ratu Watershed, Nepal

\section{Editors}

Narendra R. Khanal

Central Department of Geography, Tribhuvan University, Kirtipur, Kathmandu, Nepal

Mandira Shrestha

International Centre for Integrated Mountain Development, Khumaltar, Lalitpur, Nepal

Motilal Ghimire

Central Department of Geography, Tribhuvan University, Kirtipur, Kathmandu, Nepal

International Centre for Integrated Mountain Development (ICIMOD) 


\section{Copyright @ 2007}

International Centre for Integrated Mountain Development (ICIMOD)

United Nations International Scientific and Cultural Organization (UNESCO)

All rights reserved

\section{Published by the}

International Centre for Integrated Mountain Development

G.P.O. Box 3226

Kathmandu, Nepal

and

United Nations Educational Scientific and Cultural Organization (UNESCO)

UNESCO House

B-5/29, Safdarjung Enclave

New Delhi-110029, India

\section{ISBN 978-92-9115-018-2}

Photo credit: Women involved in flood disaster preparedness in the Ratu Khola - Mandira Shrestha

\section{Editorial Team}

Greta M. Rana (Consultant Editor)

Joyce M. Mendez (Editor)

A. Beatrice Murray (Senior Editor)

Dharma R. Maharjan (Technical Support and Layout Design)

\section{Printed and bound in Nepal by}

Hill Side Press $(P)$ Ltd.

Kathmandu

\section{Reproduction}

This publication may be reproduced in whole or in part and in any form for educational or non-profit purposes without special permission from the copyright holder, provided acknowledgement of the source is made. ICIMOD and UNESCO would appreciate receiving a copy of any publication that uses this publication as a source.

No use of this publication may be made for resale or for any other commercial purpose whatsoever without prior permission in writing from ICIMOD or UNESCO.

\section{Note}

The designations employed, the presentation of material, and the views and interpretations in this publication are those of the author(s). They are not attributable to ICIMOD or UNESCO and do not imply the expression of any opinion whatsoever concerning the legal status of any country, territory, city or area of its authorities, or concerning the delimitation of its frontiers or boundaries, or the endorsement of any product. 


\section{Study team for the Ratu Watershed}

\section{Tribhuvan University}

Professor. Khadga Bahadur Thapa, Central Department of Hydrology and Meteorology: Coordinator

Dr. Narendra Raj Khanal, Central Department of Geography

Dr. Narendra Shakya, Institute of Engineering

Mr. Motilal Ghimire, Central Department of Geography

International Centre for Integrated Mountain Development

Ms. Mandira Shrestha, Coordinator

Technical team for field investigations

Mr. Deepak Poudel

Mr. Rishi Kesh Rijal

Mr. Chitra Prasad Acharya

Mr. Purna Bahadur Thapa

Mr. Yadav Subedi

Mr. Ripendra Awal

Mr. Ram Krishna Regmi 


\section{Contents}

Foreword

Acknowledgements

Executive Summary

Acronyms and Abbreviations

Chapter 1: Flood Hazard, Risk and Vulnerability in Nepal: the Physical and Socioeconomic Environment

Introduction

Physical and Socioeconomic Environment of Nepal

Types, Magnitude, and Frequency of Natural Disasters in Nepal

Floods

Vulnerabilty

Mapping and Past Assessment Efforts

ICIMOD's Activities

Chapter 2: Mapping Flood Hazard and Risk in a Vulnerable Teral Region: The Ratu Watershed

Introduction

Objectives

The Study Area

Methodology

Results

Chapter 3: Preparing for Disaster, Reducing Risk, Building Resilience: Study Results and Recommendations 69

Introduction

Methodology

Results

Vulnerability

Chapter 4: The Larger Picture

Conclusions

Recommendations 


\section{List of Figures}

Figure 1.1: Nepal administrative divisions and ecological regions

Figure 1.2: Nepal physiographic regions and drainage network

Figure 1.3: Physiographic regions vis-à-vis major geological formations of the Nepal Himalaya

Figure 1.4: Nepal distribution of mean annual rainfall

Figure 1.5: Loss of life from different natural disasters in Nepal, 1983-2005

Figure 1.6: Families affected by different natural disasters in Nepal, 1983-2005

Figure 1.7: Estimated amount of property lost, 1983-2005

Figure 1.8: Annual loss of life and property from landslides, floods, and avalanches

Figure 1.9: Frequency of flood and landslide hazards and impact by district

Figure 2.1: Map of the study area

Figure 2.2: General geomorphology of the Ratu Khola Basin

Figure 2.3: Topographic profile of the basin along a north-south cross-section

Figure 2.4: Mean monthly temperature recorded at Jaleshwar, 1969-1996

Figure 2.5: Mean monthly rainfall recorded at Jaleshwar, 1969-1996

Figure 2.6: Mean monthly rainfall recorded at Tulsi, 1956-1996

Figure 2.7: Longitudinal profile of the Ratu Khola and Jangha Khola

Figure 2.8: River network traced from aerial photos and imagery at different periods $\quad 35$

Figure 2.9: A closer view of the river channel network, 1954-1999 36

Figure 2.10: Channel width of the Ratu Khola measured at different cross-sections 36

Figure 2.11: Land use and land cover types, 1996

Figure 2.12: Population density by VDC 40

Figure 2.13: Level of income by VDC 40

Figure 2.14: Percentage of landless and marginal farm households by VDC 40

Figure 2.15: Percentage of food-deficit households by VDC 40

Figure 2.16: Samples of aerial photographs used for mapping 44

Figure 2.17: Image interpretation using FCC, 432, and $751 \quad 45$

Figure 2.18: Delineation of flood-prone areas by local people during group discussion 46

Figure 2.19: Flood-hazard mapping scheme adopting geomorphic approach 47

Figure 2.20: Vulnerability and risk-mapping scheme 48

Figure 2.21: One-dimentional floodplain analysis using HEC-RAS,GIS, and HEC-GeoRAS 50

Figure 2.22: Process flow diagram for using HEC Geo RAS $\quad 51$

Figure 2.23: Flood-affected areas, 1978/79 aerial photos 53

Figure 2.24: Flood-affected areas, 1992 aerial photos 54

Figure 2.25: Flood-affected areas, 1999 Landsat TM imagery $\quad 55$

Figure 2.26: Terrain unit map 56

Figure 2.27: Old river channel courses $\quad 58$

Figure 2.28: Moist areas and marshes $\quad 60$

Figure 2.29: Potential areas of river-bank cutting 61

Figure 2.30: Composite flood-hazard map 62

Figure 2.31: House units and built-up areas at risk from flood hazard 63

Figure 2.32: Theoretical inundation due to flow intervention by a structure at the Indo-Nepal border

Figure 2.33: Vulnerability and risk maps $\quad 65$

Figure 2.34: Two-year return flood with 50 and 100\% flow 66

Figure 2.35: Five-year return flood with 50 and $100 \%$ flow 66

Figure 2.36: Flood-hazard maps: social and geomorphic approach $\quad 67$

Figure 3.1: Location of areas selected for the micro-level study 73

Figure 3.2: Loss of life and property from flood hazards, 1961.2003 79

Figure 3.3: Households with food sufficiency 83

Figure 3.4: Money spent on various emergency measures $\quad 84$

Figure 3.5: Contributions made by various agencies/institutions for mitigation measures 85

Figure 3.6: Flooded area versus water depth for different flood discharges 87 
Figure 3.7: $\quad$ Discharge flooded depth and area $\quad 88$

Figure 3.8: Evacuation route on hazard map for $160 \mathrm{~m}^{3} / \mathrm{s}$ discharge 90

Figure 3.9: Evacuation route on hazard map for $180 \mathrm{~m}^{3} / \mathrm{s}$ discharge 90

Figure 3.10: Evacuation route on hazard map for $507.52 \mathrm{~m}^{3} / \mathrm{s}$ discharge 91

Figure 3.11: Evacuation route on hazard map for $1016.37 \mathrm{~m}^{3} / \mathrm{s}$ discharge 91

\section{List of Tables}

Table 1.1: $\quad$ Average annual loss of life and property from natural disasters, 1983-2005 8

Table 1.2: $\quad$ Losses from floods, landslides, and avalanches, 1983.2005 12

Table 1.3: $\quad$ Losses from floods and landslides by ecological region, 1992-2001 14

Table 1.4: $\quad$ Socioeconomic indicators of Nepal and other countries in South Asia 18

Table 2.1: Maximum rainfall at Tulsi and Jaleshwar with various return periods 34

Table 2.2: $\quad$ Peak discharge at various sites along the Ratu Khola 37

Table 2.3: $\quad$ Area under different land-use and land-cover types 38

Table 2.4: Colour composites and individual bands of the LANDSAT Thematic

Mapper and land features $\quad 45$

Table 2.5: $\quad$ Areas by flood-hazard types $\quad 59$

Table 3.1: $\quad$ Frequency of different natural hazards and their recurrence intervals $\quad 75$

Table 3.2: $\quad$ Annual loss of life caused by different hazards $\quad 75$

Table 3.3: Annual loss of property caused by different hazards 76

Table 3.4: Annual household income and losses among households in flood-prone areas 77

Table 3.5: Annual loss of life and property caused by flood hazards 78

Table 3.6: $\quad$ Average annual losses and damage 79

Table 3.7: Number of households exposed to water-induced disasters 80

Table 3.8: $\quad$ Land use in areas susceptible to flooding $\quad 81$

Table 3.9: $\quad$ Percentage of households with different levels of vulnerability 82

Table 3.10: Area, production, and yield in the hazard-prone area 83

Table 3.11: Estimated cost of proposed emergency measures 86

Table 3.12: Estimated cost of proposed mitigation measures 86

Table 3.13: $\quad$ Rainfall events producing flood events $\quad 87$

Table 3.14: Classification of relief routes, distance, and shelter areas for different localities 89 
The devastating impacts of floods on local Himalayan communities as well as downstream residents has been an enduring concern for both ICIMOD and UNESCO as well as our partners. Riverine and flashfloods cause more damage to lives, livelihoods, and infrastructure annually than any other natural calamities in the Himalayan region. This has led both ICIMOD and UNESCO to encourage regional collaboration in the study and sharing of mitigation measures on floods as well as river systems and the interaction between the mountain and plains that these rivers induce. One of the platforms that we have created to forge regional cooperation in the region is the HKH FRIEND. Since its inception in March 1996, $\mathrm{HKH}$-FRIEND has been contributing to improve the understanding of the regional water resources and their behaviours in the HKH region.

The advancement in computer-aided and space-based technology such as geographic information systems (GIS) and remote sensing (RS) has proved very useful in studying and mapping the flood-hazards and developing measures that can be useful to the local communities as well.

This study documents the use of flood-hazard mapping as a way of helping communities to devise plans that would help them develop warning and response systems. This allows communities to prepare a management plan that will boost their resilience to mitigate damages and salvage their livelihoods to the extent possible. This is especially critical for the women and poor within these communities who are the ones to suffer the greatest and the ones with the least ability to recover their meager assts.

This study and flood-hazard mapping of the Ratu Khola watershed in Nepal seeks to encourage others to undertake similar work. The results obtained were of direct use to the communities concerned. More importantly, they illustrate an approach that can be used more widely.

This study has been published at a time when the HKH FRIEND has been put through an evaluation and efforts are underway to revamp and reorganise this regional set up.

ICIMOD and UNESCO-New Delhi were pleased to work together in this important project. We hope the study will not only save lives and livelihoods in Ratu Khola but also provide a basis for replication throughout the Himalayan region.

J. Gabriel Campbell

Director General

ICIMOD
Minja Yang

Director and Representative UNESCO-New Delhi 


\section{Acknowledgements}

We express our sincere gratitude to UNESCO for providing us with both financial and programme support to carry out this work. Special thanks go to the MENRIS Division of ICIMOD for providing the satellite imagery. We would also like to acknowledge the help of the Department of Survey, Ministry of Land Reform and Management, Government of Nepal in providing aerial photographs and topographic maps, and the Forest Research and Survey Centre, Forest Survey Division, Government of Nepal for providing aerial photographs from 1953/54. Thanks are also due to the Department of Hydrology and Meteorology, GoN, for making available climate data recorded at meteorological stations located within and near areas of the Ratu Watershed.

We would like to thank Bhanu Neupane, Regional Programme Specialist of UNESCO, for his comments and support. We would also like to express our sincere gratitude to Suresh Raj Chalise and Richard Heggen, who accompanied us in the field study and provided valuable guidance and suggestions. Thanks are also due to Mr. Pradeep Man Dangol of ICIMOD who helped in various capacities in the accomplishment of this study, and Xu Jianchu whose encouragment and guidance helped to make this publication possible. The valuable inputs of the Publications Unit is gratefully acknowledged, especially Greta M. Rana, Consultant Editor, Joyce M. Mendez, who oversaw preparation of the publication, Dharma R. Maharjan, who did the design and layout, and Asha K. Thaku, who helped modify many of the figures and maps. Last but not least, our heartfelt gratitude goes to all the local people who participated in the group discussions and provided us with valuable insights and information. 


\section{Executive Summary}

Flood hazards, their impact, and the resilience of communities have been assessed here on three spatial scales - national at macro-level, watershed at meso-level, and village development committee/municipality at micro-level. At national level, the impacts from different environmental hazards have been assessed, whereas at watershed level the focus was on hazard, risk, and vulnerability mapping. The Ratu Watershed in the Central Terai (Mahottari and Dhanusa districts) was selected for mapping. At micro-level, the focus was on enhancing the resilience of local people to cope with and recover from flood hazard. Rajbas in the upstream area and Jaleshwar municipality in the downstream area were selected for micro-level activities. The study was coordinated by the International Centre for Integrated Mountain Development (ICIMOD) with support from the United Nations Education, Scientific and Cultural Organization (UNESCO), New Delhi, India.

Floods occur repeatedly in Nepal and cause tremendous losses in terms of property and life, particularly in the lowland areas of the country. Hence, they constitute the main hazard. Floods that cause substantial devastation in Nepal are triggered by five different mechanisms: continuous rainfall and cloudbursts, glacial lake outbursts, landslide dam outbursts, failure of infrastructure, and sheet flooding or inundation as a result of excessive rain, bank overflow, or obstruction to the flow from infrastructural development. Nearly $77 \%$ of the total losses caused by water-induced disasters - floods, landslides, and avalanches - occur in the Terai region where the main water-induced disasters are floods. An extremely rugged, diverse, and dynamic mountain landscape; the fact that the country is landlocked; inaccessibility; dispersed human settlements; and a high rate of territorial mobility among the population are the main causes of extreme physical and locational vulnerability to floods and landslide disasters. Moreover, socioeconomic conditions characterised by a poor human development profile, low level of economic growth, mass poverty, and a great disparity in the distribution of productive assets and income, in addition to inadequate provision of services and lack of political stability, commitment, and accountability, increase the vulnerability to natural disasters and constrain appropriate response and augmentation of resilience to disasters.

Flood-hazard, risk, and vulnerability mapping in the Ratu Watershed was carried out through three different approaches: a geomorphic approach using a geographical information system (GIS) and remote sensing (RS), measurement of rainfall-runoff processes using the Hydrological Engineering Corporation's River System Analysis (HEC-RAS) model, and social flood hazard mapping based on local experiences. The main sources of information were maps, aerial photographs, selected imagery, household survey and group discussions, field 
observations, and published and unpublished documents. GIS-based softwares, such as ArcView, the Integrated Land and Water Information System (ILWIS), and the Hydrological Engineering Corporation's River System Analysis [U.S.Army Corps] (HEC-RAS and HEC-GeoRas) were used for data processing and analysis.

Flood risk and vulnerability maps prepared for the Ratu Watershed show that nearly $18 \%$ of the area is in the high-risk category. Inundation-hazard maps show that a large part of the area in the south, near the Nepal-India border, is subject to extensive inundation even by floods in the two-year return category. A comparison of hazard maps prepared based on the three different approaches shows that GIS and RS are useful for mapping the flood hazard, risk, and vulnerability of a large area at watershed level.

Flooding, cutting of river banks, and shifting channels, are the most frequently occurring water-induced disasters in the lowland area of the Ratu Watershed. On average, nearly $8 \%$ of the total annual household income is lost as a result of floods. Nearly $61 \%$ of the households in the watershed are exposed to flood hazards, among them, $21 \%$ of the households are situated in high-hazard areas.

The risk of flooding and its associated processes, such as a rise in the river bed, cutting of river banks, and shifting channels, in the Ratu Watershed is great. Moreover, the risk of inundation has increased over recent years because of added infrastructure such as roads and bridges. This is the case not only in Nepal but also in the nearby border area in India.

Responses to flood hazards are confined to rescue and relief during flooding and some mitigation measures such as construction of dams, spurs, retaining walls, plantation, and drainage management. These activities are insufficient, on the one hand, and, on the other, there are no activities or programmes on flood preparedness. People in the locality realise the importance of incorporating components of watershed conservation and drainage management through proper land-use guidelines, income-generating activities, community-based early warning systems, and awareness creation in plans for watershed conservation. They also realise the need for a local institutional network to design and implement such activities.

An attempt was made to develop a community-based early warning system and identify safe evacuation routes and areas safe for shelter in order to improve the local capacity to respond and manage flood hazards during the second phase of the project. In this context, people were trained to read and record precipitation and discharge in upstream areas; and discussions took place on the use of maps of safe evacuation routes and shelters in downstream areas. The benefits of these efforts have yet to be realised through organising and networking to establish an early warning system and by creating awareness. 
This publication is a summary of a detailed study on flood-risk and vulnerability mapping of the Ratu Khola using GIS methods. It is divided into four chapters. Chapter One describes the biophysical and socioeconomic characteristics of Nepal, discusses the types, frequency, and magnitude of losses from different types of natural disaster and their spatial concentration with special reference to flood disasters, and assesses the vulnerability to flood hazards in the country. Chapter Two describes flood-hazard and risk mapping in the Ratu Watershed. This chapter provides details of the project area and the methodology for and results of hazard, risk, and vulnerability mapping. Chapter Three gives an account of the assessment carried out on response and resilience in the context of hazard, risk, and vulnerability in the Ratu Watershed. Chapter Four covers the main findings, conclusions, and recommendations. 


\section{Acronyms and Abbreviations}

\begin{tabular}{|c|c|}
\hline AV-RAS & Arc View Extension for River Analysis System \\
\hline DPI & dots per inch \\
\hline DTM & digital terrain model \\
\hline DWIDP & Department of Water Induced Disaster Prevention \\
\hline FCC & false colour composite \\
\hline HEC-RAS & $\begin{array}{l}\text { Hydrological Engineering Corporation, River System Analysis, US } \\
\text { Army Corps }\end{array}$ \\
\hline IHP & International Hydrological Programme \\
\hline ILWIS & Integrated Land and Water Information System \\
\hline LRMP & Land Resources Mapping Project \\
\hline JICA & Japan International Cooperation Agency \\
\hline MBT & Main Boundary Thrust \\
\hline MCT & Main Central Thrust \\
\hline RGB & red green blue \\
\hline RMS & root mean square \\
\hline TM & thematic mapper \\
\hline $\mathrm{TIN}$ & triangular irregular network \\
\hline UNDRO & United Nation's Disaster Relief Organization \\
\hline WECS & Water and Energy Commission Secretariat \\
\hline WMO & World Meteorological Organization \\
\hline $3 D$ & three-dimensional \\
\hline
\end{tabular}

\section{Currency Equivalent}

US $\$ 1=$ NRs 73.69 (as of 10 September 2006) 